\title{
Implications of a Pandemic Outbreak Risk: A Discussion on China's Emergency Logistics in the Era of Coronavirus Disease 2019 (COVID-19)
}

Author(s): Yui-yip Lau, Zhang Jiamian, Ng Adolf K. Y., Roozbeh Panahi

Source: Journal of International Logistics and Trade 2020; 18(3):127-135

Published by: Jungseok Research Institute of International Logistics and Trade, Inha University

DOI: https://doi.org/10.24006/jilt.2020.18.3.127

The Journal of International Logistics and Trade is an official journal published by Jungseok Research Institute of International Logistics and Trade, Inha University, Korea. JILT welcomes manuscripts that advance the practice and science of logistics, trade, and other related fields.

Frequency: Quarterly (March, June, September, December)

Stable URL: https://www.ejilt.org

The Jungseok Research Institute of International Logistics and Trade is a specialized academic research institute representing Inha University and the Inha Foundation in Korea. The institute aims to become a representative institute in Northeast Asia in the research of logistics and trade.

Stable URL: https://jrieng.inha.ac.kr

(C) Copyright. Jungseok Research Institute of International Logistics and Trade.

This is an Open-Access article distributed under the terms of the Creative Commons Attribution NonCommercial License (http://creativecommons.org/licenses/by-nc/4.0/) which permits unrestricted noncommercial use, distribution, and reproduction in any medium, provided the original work is properly cited 


\title{
Implications of a Pandemic Outbreak Risk: A Discussion on China's Emergency Logistics in the Era of Coronavirus Disease 2019 (COVID-19)
}

\author{
Yui-yip Lau ${ }^{1,}{ }^{*}$, Zhang Jiamian ${ }^{1}$, Ng Adolf K. Y. ${ }^{1,2}$, Roozbeh Panahi ${ }^{3}$ \\ ${ }^{1}$ Division of Business and Hospitality Management, College of Professional and Continuing Education, The Hong Kong Polytechnic University, Hong Kong \\ ${ }^{2}$ St. John's College, University of Manitoba, Winnipeg, MB, Canada \\ ${ }^{3}$ Department of Supply Chain Management, Asper School of Business, University of Manitoba, Winnipeg, MB, Canada
}

Received August 12, 2020
Revised September 06, 2020
Accepted September 14, 2020

*Corresponding author: Yui-yip Lau
Division of Business and Hospitality
Management, College of Professional and
Continuing Education, The Hong Kong
Polytechnic University, Hong Kong
Tel: +852-37460648
E-mail: yuiyip.lau@cpce-polyu.edu.hk

Received August 12, 2020

Revised September 06, 2020

\begin{abstract}
Emergency logistics is an important means to deal with disasters and public crises. Since the outbreak of the severe acute respiratory syndrome (SARS) virus in 2003, China has established and developed an emergency logistics management system. With the outbreak of coronavirus disease (COVID-19) in China, its emergency logistics system is facing unfolded challenges. The main purposes of this study are to explore the development of China's emergency logistics system in this context and identify the critical success factors for such systems. A series of focus groups are organized to collect the opinions of 24 interviewees from three Chinese cities, namely Wuhan, Shanghai, and Xi'an. Through the analysis, a framework of the critical success factors for emergency logistics in China is recreated. The key elements are demand forecasting and planning, inventory management, distribution network, and systematic information management. Findings suggest critical points on the design and imple-mentation of the emergency logistics operations during a chaotic period.
\end{abstract}

Keywords Emergency logistics, China, Coronavirus disease (COVID-19)

\section{Introduction}

The volume and effect of human and natural-related disasters have been rising, stemming from the 1950s (Boonmee et al. 2017). The emergence of an epidemic disease may create an immense hazard to human beings. In an abortive control, it is easily become a pandemic and gives rise to a global crisis (Yu et al. 2020). According to the World Health Organization (WHO) website, an epidemic outbreak is defined as "the occurrence of disease cases in excess of normal expectancy". In general, an epidemic is induced by an infectious disease with hazardous and radioactive chemical origin, or animal-to-human or humanto-human transmission (Tang and Lau 2013). Human beings are considered as the leading reservoir of the disease because infection is long-lasting. During the 1990s, several cases of infectious disease were addressed (Raoult et al. 1998). Starting from 2000, the outbreak of infectious disease threatened global development, the international community, and human life like H5N1 avian influenza, severe acute respiratory scheme (SARS), Swine Flu, the Ebola virus, and the Middle East respiratory syndrome coronavirus (MER-Cov). Although infectious disease outbreak usually starts small, their scales are fast and spreading over various geographical zones (Ivanov 2020). Findlater and Bogoch (2018) addressed that the rising access and speed of human mobility, shifting geographical allocations of disease vectors, and rising volumes of human travel (i.e., air travel) and trade are the driving forces of the global disperse of epidemic diseases. In particular, an unknown MERS-CoV in Saudi Arabia has spread to remote countries (e.g., Korea). In reality, government bodies, policymakers, researchers, industry practitioners, and health specialists feel great anxiety as infectious diseases disperse produce global panic.

Recently, coronavirus disease 2019 (COVID-19) has rapidly spread in different parts of the world. Until now, there are neither particular antiviral treatments nor vaccines for COVID-19. As a result, it has happened in almost all countries crossing all six WHO regions (i.e., Americas, Europe, South-East Asia, Eastern Mediterranean, Africa, and Western Pacific). Clearly, the number of COVID-19 cases is has dramatically risen in the U.S., Europe, and Asia regions bringing about quarantines and “lock-down” policies (Ivanov 2020). Araz et al. (2020) emphasize that the COVID-19 outbreak constituted one of the crucial disruptions experienced during the half-century "breaking many global supply chains”. 94\% of the Fortune 1,000 firms have 
been indicated observing COVID-19 interrupted supply chain operations (Sherman 2020). Numerous well-established facilities (e.g., warehouses, factories, distribution centers) are now located in COVID-19's quarantine areas in Korea, China, and Italy, as well as various items sourced mainly from the quarantined regions in China. It is sensible that COVID-19 creates concurrent both demand and supply turmoil (Ivanov 2020).

In early August 2020, there have been accumulated almost 18,000,000 confirmed cases of COVID-19, including around 700,000 deaths globally. Accordingly, WHO affirmed the COVID-19 outbreak induce a public health emergency of international concern (WHO 2020). In such case, COVID-19 gives rise to a significantly risen demand for different resources (e.g., healthcare facilities, medical supplies, medical staff) within a short period. To diminish the economic effects, support the control of disease, and offer a considerable and prompt medical service, it is vital to develop emergency logistics. Its purpose is to improve the efficiency of rescue operations and to mitigate negative impacts on the human life (Caunhye et al. 2012). As pointed out by Kovács and Spens (2009), instant emergency responses are required to diminish the damages and save lives once a considerable disaster and disease occurs. In doing so, material distribution and facility location in emergency logistics are in vital connection with rescue operations and which should be considered in emergency decision making (Xu et al. 2018). With globalization, the impact of emergencies is not limited to a specific country or region. Thus, it is urgent to study how to deal with emergencies and what measures should be taken to side effects. Since the outbreak of the SARS virus in 2003, the Chinese government has continuously developed and optimized emergency logistics. Considering the global outbreak and rapid spread of new coronal pneumonia virus, this is a huge challenge for China's emergency logistics system. Unsurprisingly, Jiang and Yuan (2019) addressed that emergency logistics research have increased sharply after 9/11 in the US. Nevertheless, numerous emergency logistics research studies are inclined toward the operations research community. This is dominated by the disaster operations management (Altay and Green III 2006; Galindo and Batta 2013), cyber and traffic space safety (Wright et al. 2006), and terrorist attack (Wanying et al. 2016). The research studies of emergency logistics relevant to disease are often overlooked. To fill this important research gap, this study explores the current situation of China's emergency logistics development by taking the current new coronary pneumonia virus as the research background along with the implications of COVID-19 in emergency logistics management. Also, we explore the critical success factors for emergency logistics in China.

The rest of the paper is structured as follows. In Section 2, we review the relevant theories to establish the theoretical basis of emergency logistics, including definitions, characteristics, and other relevant parts. The current situation of COVID-19 in China is also discussed. The process of data collection, including the sample selection and specific steps are provided in Section 3. Main research findings are then discussed in Section 4. The conclusion can be found in Section 5.

\section{Literature review}

\subsection{Emergency logistics}

Emergency logistics has been concentrated on regular emergencies and urban emergency services since the 1960s. Scholars have made different explanations for the connotation of emergency logistics. In a recent study, it is defined as "the logistics activities caused by emergencies, including emergency logistics demand generated by emergencies and emergency logistics supply activities to meet these logistics needs, pursuing the purpose of maximizing time efficiency and minimizing disaster losses” (Xu et al. 2018: 188). An emergency logistics plan, execute and control a series of special logistics activities to deal with major natural disasters or public emergencies. Caunhye et al. (2012) argued that emergency logistics means a series of emergency logistics safeguard measures to deal with emergencies. In doing so, emergency logistics is to meet the sudden logistical needs, abnormal organization of goods from the place of supply to the place of acceptance of the entity flow process. In addition, Wang et al. (2015) pointed out that emergency logistics is a kind of logistics operation mode in response to unexpected events, which means special logistics activities are caused by unexpected factors or events. The common point of the above definitions is that the reason for emergency logistics is an emergency. The goals are to fulfill emergency demand and perform basic logistics activities.

In the same vein, scholars made different explanations on the purpose of emergency logistics. Liu and Liu (2011) claimed that the direct purpose of emergency logistics system is to realize the space and time benefits of materials and to highlight the linkage of each actor in the logistical activities. Also, Sheu (2010) identified the main objectives of creating an emergency logistics system, namely to improve the openness, scalability, and rapid response abilities of the logistical system. Specifically, the goal of building the emergency logistics system is to obtain the emergency materials needed in the shortest time and at the lowest cost and to transport the emergency materials to the appropriate place in the appropriate time by the appropriate means 
of transport, and finally distribute them to the demander's manual center in the appropriate way.

As suggested by Wang et al. (2015), when emergency logistics is activated by emergencies, it is necessary to assess the material demands of the people, local production capacity, and supplementary supplies. The assessment covers the extent and type of damage caused by emergencies, as well as areas in an urgent need of rescue. Here, the rules of assessment include the type, quantity, urgency, supply place of rescue materials, transfer place, to name but a few. Due to the continuous evolution and change of damage caused by emergencies, assessment should not be based only on the current situation, but also the prediction of future demands. Abdul (2018) argued that the planning strategy of emergency logistics needs to consider the operation strategy of logistics company, distribution center setting, outsourcing scheme of business, commercial budget scale, financial support, distribution of origin of transportation materials, and distribution of main destinations of the transportation business.

In this regard, inventory management is one of the core functions of emergency logistics, involving the planning, coordination, and control of emergency materials in the supply chain. According to Ozguven and Ozbay (2013), the quantity and time demand for goods are directly affected by material supply and demand. To this end, inventory management needs to be adjusted at any time to align the changing actual demand. In addition, inventory management in emergency logistics is different from traditional logistics. The time value of emergency logistics far exceeds the transportation cost of inventory. In this case, emergency logistics management requires the establishment of warehouse(s) where emergency materials can be stored in key locations. Hence, when an emergency occurs, it can respond quickly in the shortest time.

Also, transportation is a key element of the emergency logistics operation. Based on Liu et al. (2012), emergency materials can be transported to places where they need to be in various ways. Thus, a reasonable setting of resettlement points or transfer stations is conducive to the distribution of emergency main groups. The specific tasks include adding loading and unloading equipment at the temporary transfer point and reasonably planning the types of vehicles and cargo characteristics to enter the disaster area. To minimize the loss of the intermediate process and maximize the effective use of emergency resources, it is necessary to develop a comprehensive process to monitor the flow of emergency materials. In this way, we need to plan the route and register the types, quantities, and transportation directions of goods at each transit station. Next, emergency material transportation capacity planning refers to the determination of the number and capacity of warehouses or distribution centers, the allocation of vehicles, and personnel for each warehouse or distribution center according to the short-term and long-term common needs. When determining the transportation strategy, it is not only the emergency material transportation capacity, mode, and resources that need to be considered, but a backup plan should be drawn up to prevent unpredictable emergencies (Wang et al. 2018).

Information system is the core function of emergency logistics and is the basis of regulating the flow of logistics direction. Chen and Hua (2014) investigated the information management system of emergency logistics needs to accurately collect the basic data needed by the system, establish a complete database, and update it in a timely manner. Importantly, information processing and transmission should be fast and reliable. Furthermore, the auxiliary decision-making system of emergency logistics organization and command should be established for different types of emergencies.

Based on Jiang and Yuan (2019), emergency logistics needs to encounter four major risks, namely the diversity of demand, the urgency of demand, multi-agent participation, and logistics overload. In addition, Cheng and Yu (2010) noted that emergency logistics exhibits weakness of particular functions. Specifically, the shortage of materials and the deterioration of transportation infrastructure often make emergency logistics only perform the basic functions of normal logistics. The necessary functions are often weakened or omitted accordingly.

\subsection{COVID-19 in China}

COVID-19 outbreak spread from Wuhan area. At this time, The Centers for Disease Control and Prevention (CDC) identified there was a series of unrevealed pneumonia cases that emerged in Huanan seafood wholesale market. Common symptoms characteristics pertaining to fatigue, dry cough, and fever, and then followed by myalgia, anorexia, and dyspnea (Li et al. 2020). A new coronavirus was recognized as the source of pneumonia. In reality, a lack of particular vaccines or therapeutic drugs for COVID-19 leads to COVID-19 promptly affected all provinces of mainland China within 2 months (Ai et al. 2020). In response to the quick spreading of COVID-19, each province of Mainland China introduced the highest response level to the public health crisis (CDC 2020). Such as adopting the "lock-down" policy or promptly separatinge the disease-ridden person from the healthy population (Ai et al. 2020). Between January $8^{\text {th }}$ and March $3^{\text {rd }} 2020$, the number of confirmed coronavirus disease cases have reached 80,306 with a further rise to 88,804 cases, including 4,684 deaths as of 6 August 2020 (WHO 2020).

The cumulative COVID-19 cases of each province in China can be found in Figure 1. Interestingly, different COVID-19 risk 


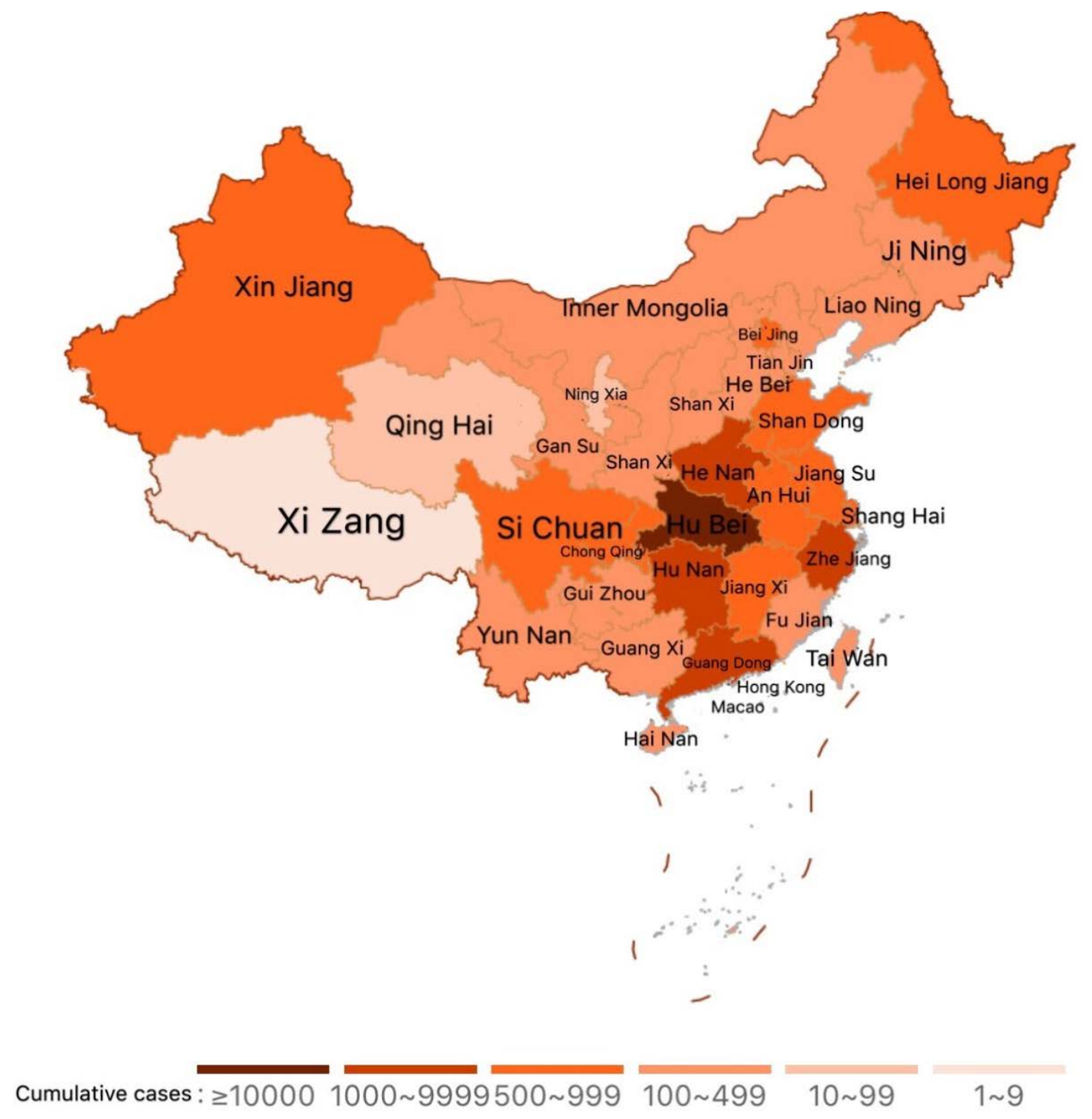

Figure 1. Cumulative COVID-19 cases in China. COVID-19, coronavirus disease 2019.

Source: The Centers for Disease Control and Prevention (CDC), 2020

levels are widely-distributed. More cumulative COVID-19 cases indicate that the province encounters with a higher COVID19 risk level. Hubei suffered the most, followed by Henan, Hunan, Zhejiang, and Guangdong. Sichuan, Shandong, Jiangsu, Anhui, Shanghai, Jiangxi, Beijing, Xinjiang, and Heilongjiang suffered a medium COVID-19 risk level, while Inner Mongolia, Gansu, Shanxi, Tianjin, Liaoning, Jining, Yunnan, Guizhou, Guangxi, Fujian, Hainan enjoyed relatively low risk. Three provinces, namely Xizang, Qinghai, and Ningxia identified fewer than 100 cases.

\section{Data collection}

In this study, the coronavirus pandemic was used as the case to assess the current situation of China's emergency logistics. In such case, the focus group is used as the main method to collect qualitative data. A focus group means an open discussion session on specific issues and phenomena. Based on Barbour (2007), focus groups indicate that specific groups of people are selected to have a free-form discussion of a topic to obtain first-hand, detailed information, and ideas hidden in people's hearts. In addition, a focus group can provide real and credible information about the issues to be studied. It is because everyone is equal in the discussion, and they are encouraged to express their own ideas or even reject others' explanations. In this study, 
we inclined towards using focus group interview as we can explore uncover issues and ideas that we have not taken consideration and obtain the flexibility of investigating deeper into issues during the discussion.

Focus group sampling is also an important part of data collection. Considering that China has many cities and their economic development is very different. In addition, they are affected to different degrees by the new coronal pneumonia virus. Therefore, the study selected respondents from three Chinese cities, namely Wuhan, Shanghai, and Xi'an. Wuhan is a moderately developed city and a new type of pneumonia virus in China's disaster area; Shanghai is a highly developed city and the epidemic situation is moderate; Xi'an is a relatively less developed economic area and is less affected by the virus. The study invited eight respondents from each city to participate in the study. We defined the group based on the participants' age, class, location, gender, and educational level. Indeed, the participants experienced in emergency logistics under the context of COVID-19. Thus, the participants could actively involve a discussion about an area of interest or a specific topic. During the discussion, we performed as a facilitator to lead the focus group. To stimulate discussions, we asked open-ended questions, followed by subsequent questions. Also, we started the session with a non-threatening, fun, and open-ended questions. In addition, we redirected the discussion once it was out of position. After multiple focus group discussions, we analyzed the results by reviewing the answers and exploring common themes or ideas (Holloway 2005). Another issue to be considered is that the diversity of sample selection can improve the comprehensiveness of focus group discussion results. Specifically, an important characteristics of the present group is that each participant's views may inspire the views of another participant, which means that the greater the differences in views, the greater the scope of discussion. Therefore, the selection of samples should consider their differences to promote more discussion on this topic. In each city's focus group, different roles were invited to discuss the event, including citizens, business travelers, drugstore staff, convenience store staff, supermarket staff, medical supplies manufacturers (i.e., surgical masks), logistics firms, and transportation operators (i.e., airlines, shipping lines).

China was still implementing strict travel control during our data collection period. As a result, the online focus group meeting was held from April to May 2020 through an online video conference and the whole process was controlled within one hour. To improve the effectiveness of focus group discussion, we have developed an outline including some key questions, but all questions are open-ended and not limited to fixed answers. In the focus group process, each participant was encouraged to express their views on China's current emergency logistics applications in response to the new pneumonia virus. All the key information was recorded. During data analysis, the key information was conceptualized, while detailed comparison and analysis were carried out to obtain the ideas of participants. As per confidentiality agreements, the details of the interviewees are not released.

\section{Findings and discussion}

Some researchers (e.g., Tun and Pathranarakul 2006; Adikaram and Nawarathna 2018; Siriporananon and Visuthismajarn 2018; Jiang and Yuan 2019) addressed the importance of disaster management in response to the rise of natural disasters. In general, disaster management and emergency logistics perform similar and different key success factors. We provide the comparison table in Table 1.

In this section, we aim at discussing the critical success factors for emergency logistics in China. We have developed a framework on the basis of our research findings (Figure 2). We propose the critical success factors pertaining to demand forecasting and planning, inventory management, distribution network, and systematic information management.

The first important finding is that demand forecasting and planning are important prerequisites for the implementation of emergency logistics. For example, a resident in Chinese cities said that they were asked to register their weekly needs, including surgical masks, necessities, and food. Also, a pharmacy staff expressed that he/she needs to register and report customer demand information regularly to the government authorities, including the demand for surgical masks and disinfectants. To manage a dynamic demand management process, the Chinese government allocated emergency supplies according to the different demands of each region. In this regard, Özdamar et al. (2004) argued that emergency logistics needed to assess the material demand of the people, local production capacity, and supplementary supplies. The evaluation included the kind and degree of loss generated by the scope of crucial demand for rescue, as well as emergencies. Specifically, the detailed rules of assessment included the type, quantity, urgency, supply place of rescue materials, transfer place, to name but a few. Furthermore, due to the continuous evolution and change of COVID-19, the evaluation needed to take consideration of existing real circumstances and the forecast of future demand. As such, the interviewees addressed that various automobile manufacturers adopted corporate social responsibility to revise the production line from automobile production to surgical mask production. Thus, it could stabilize the surgical mask supply in forthcoming days. 
Table 1. The comparison between disaster management and emergency logistics

Similarities - Multi-agency participation: May include various parties like volunteers, international support teams, and rescue teams.

- Effective institutional management leads to clear line of authority and speed up decision-making process notably for rehabilitation and emergency relief.

- The collaboration and coordination among governmental agencies, NGOs, and industrial stakeholders.

- Effective information management and sharing essential information between main stakeholders is importance for planning and rehabilitation.

\begin{tabular}{|c|c|c|}
\hline \multirow[t]{4}{*}{ Differences } & $\begin{array}{l}\text { - Logistics with damaged infrastructure. Thus, it } \\
\text { involves interdisciplinary project team members (e.g., } \\
\text { engineers, urban planners, and environmentalists) to } \\
\text { deal with unfavorable circumstances. }\end{array}$ & $\begin{array}{l}\text { - The logistics infrastructures are under favorable } \\
\text { conditions. Thus, it only needs the logistics specialists } \\
\text { to handle emergency logistics operations. }\end{array}$ \\
\hline & $\begin{array}{l}\text { - Since the disasters have occurred repeatedly, } \\
\text { supportive laws and regulations will have significant } \\
\text { effect of outcomes of disaster management. }\end{array}$ & $\begin{array}{l}\text { - Emergency logistics mainly deal with unexpected or } \\
\text { unpredictable events, supportive regulations and laws } \\
\text { may not generate a remarkable impact. }\end{array}$ \\
\hline & $\begin{array}{l}\text { - Disaster management faces serious transportation } \\
\text { management. It needs to adopt scenario and stochastic } \\
\text { based modeling with the advanced technology like } \\
\text { remote sensing tools and geographic information } \\
\text { system. }\end{array}$ & $\begin{array}{l}\text { - Emergency logistics utilizes the existing sound } \\
\text { transportation infrastructure to create a comprehensive } \\
\text { distribution networks by using simple statistical } \\
\text { analysis and common transportation technologies. }\end{array}$ \\
\hline & $\begin{array}{l}\text { - Because of the duration of disasters are last for a long } \\
\text { period, adequate resources/funds are crucial. }\end{array}$ & $\begin{array}{l}\text { - Emergency logistics mainly encounters with a short } \\
\text { period of time. Thus, reallocation of resources/funds is } \\
\text { critical. }\end{array}$ \\
\hline
\end{tabular}

Source: Siriporananon and Visuthismajarn, 2018; Jiang and Yuan, 2019.

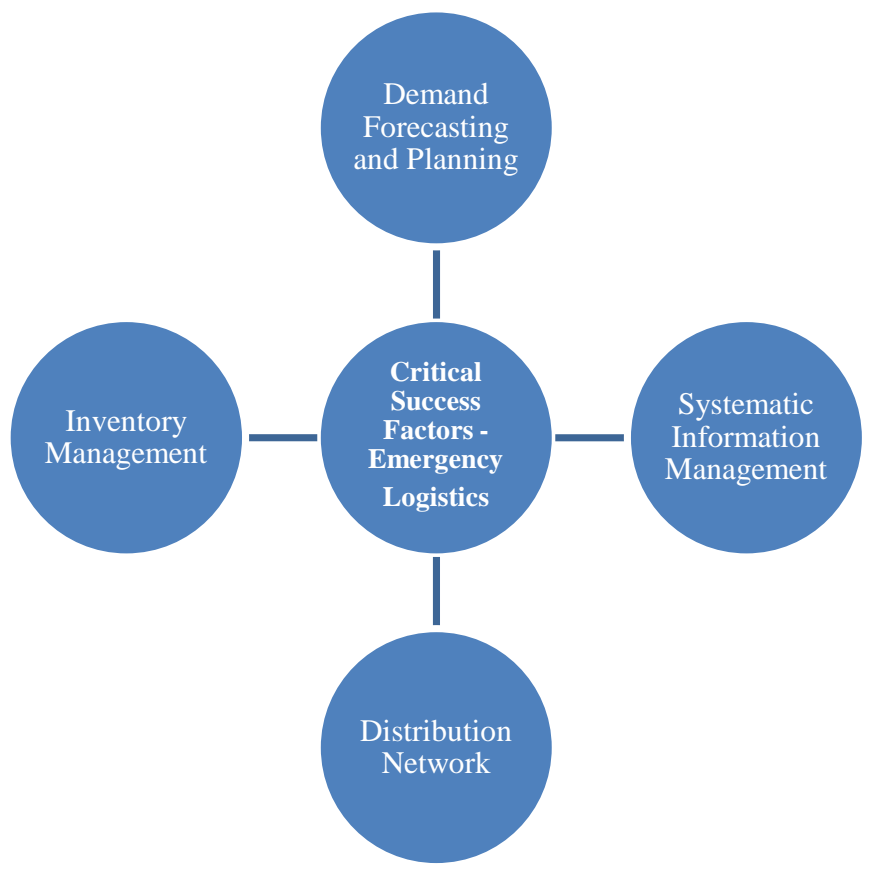

Figure 2. Critical success factors for emergency logistics in China.

Another important finding is that, as pointed out by a majority of interviewees, the availability of emergency materials became seriously inadequate at the beginning due to the seriousness of the pandemic and the labor-intensive nature of various industries (e.g., toys, shipping line, airline, textiles) that urgently demanded a large number of emergency materials and personal protection facilities. The positive aspect was that China's emergency logistics management has implemented effective inventory management. First, the inventory management of emergency materials has been effectively classified to ensure the effectiveness of inventory management. For example, a supermarket worker said that the government had taken over all supermarkets and 
required all materials to be accurately counted and classified. Different management strategies (e.g., ABC analysis) were carried out according to their importance. In the $\mathrm{ABC}$ analysis, it proposed that inventories were of unequal value to a firm. Thus, all inventories would likely be handled in a different approach. With regard to item importance, the notion of ABC could perform as " $A$ " items might be the ones with the highest cruciality, "B" items might be those with moderate cruciality, and " $C$ " items might be the one with lowest cruciality (Murrhy and Wood 2004). In this case, food and medicine were classified as the most important inventories in the current environment. Most interviewees expressed that the Chinese government set the maximum quota for each people to purchase "A" items. Such as, each Chinese resident was allowed to purchase five surgical masks at once via online registration. Based on Lodree (2012), for emergency events, there were various kinds of emergency materials and a large number of them were needed, which had high requirements for storage space and capital investment. It was not in line with the actual situation to take the same emphasis and the same inventory management model for all kinds of emergency materials. Accordingly, we must adopt the scientific classification method to classify the emergency material inventory and implement different inventory strategies for different types of emergency material inventory. Thus, the cost of inventory could be minimized and the efficiency of emergency materials be maximized. In addition, Wuhan's logistics operators pointed out that the Chinese government has established a strong inventory network to cope with the emergency. Specifically, due to strict access control measures, the government has established material storage and delivery points in communities which was a key method for every resident to get timely materials. For instance, institutions for the supply of vegetables have been set up in every community.

Findings suggest that effective distribution networks are the key factors for the success of China's emergency logistics. Interviewees indicated that the Chinese government has set up a distribution center network to ensure the effectiveness of emergency materials transportation and the reliability of food supply. Based on Feng et al. (2020), the distribution center was located in the vicinity of existing enterprises or buildings. The distribution center performed with the function of distributing production support materials. It was the transit point of the logistical network system in the regional emergency logistical systematization, which was generally distributed around the community. On the one hand, the distribution center could receive emergency materials in time. On the other hand, the distribution center could reasonably organize the replenishment and ordering of rescue materials. Based on Huang and Song (2018), the location of territorial facilities, path planning, and material inventory control were closely linked. In emergency logistics, time and cost were considered comprehensively. The integrated decision-making scheme of the three was required. According to the actual demand, the inventory strategy of the distribution center was formulated to ensure the rationality of rescue materials, so that the materials could be moved to the disaster site as soon as possible. Our interviewees from the airline industry indicated that government-owned airlines participated in distributing the emergency materials in the serious COVID-19 area via additional flight schedules. Accordingly, it could ease emergency materials storage and overcome the capacity problem of small-medium sized express companies. Due to the dynamic nature of emergencies, emergency logistics still needed to combine the development of emergencies together with the premise of real-time mastering the demand and territorial road conditions. Thus, it needed to make dynamic integrated decision on location path inventory in time.

Based on the outcomes, systematic information management is another successful foundation of emergency logistics in China. Chinese enterprises have been established since the unified information management system has been established. Specifically, all the stakeholders (e.g., large corporations, government bodies, non-governmental organizations, suppliers, logistics firms) were required to access the unified information platform. For example, the original distribution of rescue supplies, the production capacity of suppliers, and the transportation capacity of local logistics enterprises were optimized under the guidance of information. This meant that effective information coordination among production enterprises, logistics enterprises, and the government. For example, Shanghai's vegetable shortage information was passed on to the national government, and then the material supply work was supplied by Shandong Province. Based on Chen and Hua (2014), if the information can be exchanged between the enterprise and the government in time, it does not only shorten the emergency response time, improve the logistics efficiency, and reduce the cost of disaster relief, but also ensure that emergency materials can reach the emergency site accurately. Furthermore, Li (2012) suggested that a unified information system would support thorough planning, use logistics resources reasonably, carry out cross warehouse operations effectively, improve logistics efficiency, and promote information exchange.

\section{Conclusion}

Novel coronavirus pneumonia was studied to assess the current state of emergency logistics in China and identify its key 
success factors. A series of focus groups in this research provided different perspectives from three cities in China. Based on the analysis of data and relevant literature about emergency logistics concepts, this study resulted in four major findings. First, demand forecasting and planning is an important prerequisite for the implementation of emergency logistics in China. This means that the Chinese government allocates emergency materials according to the needs of different regions. Secondly, it suggests that China has implemented optimal inventory management to ensure the success of emergency logistics. The government has not only checked and classified inventory materials, but also established a strong inventory network to ensure the timeliness of materials. Thirdly, it points out that effective distribution networks is another key factor for the success of emergency logistics in China. On the one hand, the distribution center can receive emergency materials in time. On the other hand, the distribution center can reasonably organize the supplement and ordering of rescue materials. Finally, it indicates that the Chinese government has established a systematic logistics information management system to improve logistical efficiency, reduce costs, and ensure that emergency materials can reach the emergency site accurately.

Admittedly, the study has some research limitations, notably its small sample size, which mean that the results may need further verification for generalization. Thus, further research is required to collect more comprehensive data so as to improve the universality of the outcomes. Having say so, we believe that it provides very useful guidance for practitioners, policymakers, and other logistical stakeholders to design and operate emergency logistics in the future.

\section{Acknowledgements}

The authors would like to thank the editor and reviewers for their helpful comments. Also, the support by the CPCE Research Fund (project code: BHM-2019-174(E)), Canadian Institute for Health Research (CIHR) and Research Manitoba (project code: 53013), and CCAPPTIA (www.ccapptia.com) are gratefully acknowledged.

\section{References}

Abdul, S., Saba F., Mohammad, M., 2018. Emergency logistics planning under supply risk and demand uncertainty. Operational Research 20, 1437-1460.

Adikaram, K. K. N. B., Nawarathna, C. M., 2018. Business sector preparedness in disaster management: Case study with businesses in Southern Sri Lanka in both aspects of natural and technological disasters. Procedia Engineering 212, 918920.

Ai, T., Yang, Z., Hou, H., Zhan, C., Chen, C., Lu, W., Tao, Q., Sun, Z. and Xia, L., 2020. Correlation of chest CT and RT-PCR testing for coronavirus disease 2019 (COVID-19) in China: A report of 1014 cases. Radiology 296, E32-E40.

Altay, N., Green, W. G. III, 2006. OR/MS research in disaster operations management. European Journal of Operational Research 175, 475-493.

Araz, O. M., Choi, T. M., Olson, D., Salman, F. S., 2020. Data analytics for operational risk management. Decision Science. Available at: https://doi.org/10.1111/deci.12443

Barbour, R., 2007. Doing Focus Groups: The Sage Qualitative Research Kit. SAGE Publications, Los Angeles, CA.

Boonmee, C., Arimura, M., Asada, T., 2017. Facility location optimization model for emergency humanitarian logistics. International Journal of Disaster Risk Reduction 24, 485-498.

Caunhye, A., Nie, X., Pokharel, S., 2012. Optimization models in emergency logistics: A literature review. Socio-Economic Planning Sciences 46, 4-13.

Chen, W., Hua, C., 2014. The construction of emergency logistics system framework and information platform system. Applied Mechanics and Materials 580-583, 2679-2685.

Cheng, Q., Yu, L., 2010. Operational mechanism and evaluation system for emergency logistics risks. International Journal of Intelligent Systems and Applications 2, 25-32.

Feng, J. R., Gai, W. M., Li, J. Y., Xu, M., 2020. Location selection of emergency supplies repositories for emergency logistics management: A variable weighted algorithm. Journal of Loss Prevention in the Process Industries 63, 104032.

Findlater, A., Bogoch, I. I., 2018. Human mobility and the global spread of infectious diseases: A focus on air travel. Trends in Parasitology 34, 772-783.

Galindo, G., Batta, R., 2013. Review of recent developments in OR/MS research in disaster operations management. European Journal of Operational Research 230, 201-211.

Holloway, I., 2005. Qualitative Research in Health Care. Open University Press, New York, NY. 
Huang, X., Song, L., 2018. An emergency logistics distribution routing model for unexpected events. Annals of Operations Research 269, 223-239.

Ivanov, D., 2020. Predicting the impacts of epidemic outbreaks on global supply chains: A simulation-based analysis on the coronavirus outbreak (COVID-19/SARS-CoV-2) case. Transportation Research Part E 136, 101922.

Jiang, Y., Yuan, Y., 2019. Emergency logistics in a large-scale disaster context: Achievements and challenges. International Journal of Environmental Research and Public Health 16, 779-802.

Kovács, G., Spens, K., 2009. Identifying challenges in humanitarian logistics. International Journal Physical Distribution Logistics 39, 506-528.

Li, B., Yang, J., Zhao, F., Zhi, L., Wang, X., Liu, L., Bi, Z., Zhao, Y., 2020. Prevalence and impact of cardiovascular metabolic diseases on COVID-19 in China. Clinical Research in Cardiology 109, 531-538.

$\mathrm{Li}, \mathrm{W}$., 2012. The research on the emergency logistics risk analysis with incomplete information. International Journal of Advancements in Computing Technology 4, 304-310.

Liu, B., Lee, S., Jiao, Z., Wang, L., 2012. Logistics of significant events and topics. In: Contemporary Logistics in China: An Introduction. World Scientific, Hackensack, NJ.

Liu, H., Liu, L., 2011. Multi-objective location model research and application in the city emergency logistics based on different product materials. Applied Mechanics and Materials 63-64, 277-280.

Lodree, E. J., 2011. Pre-storm emergency supplies inventory planning. Journal of Humanitarian Logistics and Supply Chain Management 1, 50-77.

Murrhy, R. P., Wood, F. D., 2004. Contemporary Logistics. Upper Saddle River, NJ, Prentice Hall.

Özdamar, L., Ekinci, E., Küçükyazici, B., 2004. Emergency logistics planning in natural disasters. Annals of Operations Research 129, 217-245.

Ozguven, E., Ozbay, K., 2013. A secure and efficient inventory management system for disasters. Transportation Research Part C: Emerging Technologies 29, 171-196.

Raoult, D., Ndihokubwayo, J. B., Dupont, H. T., Roux, V., Faugere, B., Abegbinni, R., Birtles, R. J., 1998. Outbreak of epidemic typhus associated with trench fever in Burundi. The Lancet 352, 353-358.

Sherman, E., 2020. 94\% of the Fortune 1000 are seeing Coronavirus Supply Chain Disruptions: Report. Fortune. Available at: https://fortune.com/2020/02/21/fortune-1000-coronavirus-china-supply-chain-impact

Sheu, J., 2010. Dynamic relief-demand management for emergency logistics operations under large-scale disasters. Transportation Research Part E: Logistics and Transportation Review 46, 1-17.

Siriporananon, S., Visuthismajarn, P., 2018. Key success factors of disaster management policy: A case study of the Asian cities climate change resilience network in Hat Yai city, Thailand. Kasetsart Journal of Social Sciences 39, 269-276.

Tang, O., Lau, Y. Y., 2013. Logistics aspects of avian influenza pandemic in Hong Kong. International Journal Logistics Systems and Management 14, 110-131.

The Centers for Disease Control and Prevention [CDC], 2020. 01/20/2020: Lab advisory: Outbreak of 2019 novel coronavirus (2019-ncov) in Wuhan, China. Available at https://www.cdc.gov/csels/dls/locs/2020/outbreak-of-2019-novel-coronavirus2019-ncov-in-wuhan-china.html

Tun, L. M., Pathranarakul, P., 2006. An integrated approach to natural disaster management: Public project management and its critical success factors. Disaster Prevention and Management 15, 396-413.

Wang, H., Xu, R., Zijie, X., Zhou, X., Wang, Q., Duan, Q., Bu, X., 2018. Research on the optimized dispatch and transportation scheme for emergency logistics. Procedia Computer Science 129, 208-214.

Wang, L., Song, J., Shi, L., 2015 Dynamic emergency logistics planning: Models and heuristic algorithm. Optimization Letters 9, 1533-1552.

Wanying, C., Alain, G., Angel, R., 2016. Modeling the logistics response to a bioterrorist anthrax attack. European Journal of Operational Research 254, 458-471.

World Health Organization [WHO], 2020. Available at: https://www.who.int

Wright, P. D., Liberatore, M. J., Nydick, R. L., 2006. A survey of operations research models and applications in homeland security. Informs 36, 483-625.

Xu, H., Fang, D., Jin, Y., 2018. Emergency logistics theory, model and method: A review and further research directions. Advances in Computer Science Research, 65, 188-192.

Yu, H., Sun, X., Solvang, W. D., Zhao, X., 2020. Reverse logistics network design for effective management of medical waste in epidemic outbreaks: Insights from the coronavirus disease 2019 (COVID-19) outbreak in Wuhan (China). International Journal of Environmental Research and Public Health 17, 1770-1795. 